\title{
Early-age Performance of Cement Combination Concrete
}

\author{
Folagbade, S.O. ${ }^{1}$
}

\begin{abstract}
Heat of hydration up to 72 hours and compressive strength up to 7 days of Portland cement and 17 binary and ternary cements containing fly ash, silica fume, and metakaolin, at a water/cement ratio of 0.50 and addition contents of $20 \%, 35 \%$, and $55 \%$, were used to examine the early-age performance of concrete. Results revealed that early-age performance depends on the fineness, heat of hydration, and dilution effect of cement combinations. Fly ash, due to dilution effect, reduces the heat of hydration and compressive strength. Using silica fume and metakaolin with increasing content of up to $10 \%$ as binary and ternary cement components, due to their fineness and increased heat of hydration, supports the strength development. Most of the cement combinations met the standard of strength requirements for ordinary early-age performance of concrete, while only half of it satisfied the standard for high early-age performance.
\end{abstract}

Keywords: Blended cement; cement combination; compressive strength; fly ash; heat of hydration; metakaolin; silica fume; supplementary cements.

\section{Introduction}

Supplementary cementitious materials, such as fly ash, silica fume, and metakaolin, among others, due to their lower embodied carbon dioxide contents, are used primarily to reduce the environmental impact of concrete [1,2]. However, due to their low lime contents and dependence on the $\mathrm{Ca}(\mathrm{OH})_{2}$ released by the hydration reaction of Portland cement for their pozzolanic reactions, they could only be used as partial replacements for Portland cement in conventional concrete. Fly ash, due to its availability, is a primary supplementary cementitious material in concrete [3,4]. However, while it is characterised by low water demand and improved workability $[5,6]$, its use would reduce the heat of hydration $[5,7]$, retard the hydration reaction [8], and reduce the early-age performance of concrete $[9,10]$. Comparatively, the fineness of silica fume and metakaolin would increase the heat of hydration [11,12], accelerate the hydration reaction [13] and enhance the strength development [5,14-18]. However, they are expensive and could only be used in small quantities to partially replace Portland cement in concrete [19-21]. Hence, silica fume and metakaolin as ternary cement components could offset the low early-age performance of fly ash in concrete [22].

${ }^{1}$ Department of Building, Faculty of Environmental Design and Management, Obafemi Awolowo University, Ile-Ife 0220005, NIGERIA.

E-mail: samuelfolagbade@yahoo.com

Note: Discussion is expected before June, $1^{\text {st }} 2017$, and will be published in the "Civil Engineering Dimension", volume 19, number 2, September 2017.

Received 19 August 2016; revised 21 November 2016; accepted 13 January 2017.
Concrete, in practice, is specified on the basis of its 28-day strength. Also, cement combination concretes would achieve equal strength with Portland cement concrete at lower water/cement ratios [23,24]. However, if appropriately proportioned, silica fume, and metakaolin (which are costlier than Portland cement) would complement fly ash (which is cheaper than Portland cement) to produce cheaper and more environmentally compatible cement combination concretes than Portland cement concrete at equal 28 day strength [23,24]. However, the partial replacement of Portland cement with these pozzolanic materials would reduce the heat of hydration of mortar and concrete [25,26], delay the strength development and reduce the early-age performance of concrete. Hence, aside of the advantages of reduced cost and embodied carbon-dioxide content, the use of cement combination should not adversely affect the early-age performance of concrete. Also, in order to ensure cheaper and more environmentally compatible concrete with good early-age performance, well proportioned silica fume and metakaolin contents (without any additional content of Portland cement) would be needed. Hence, this paper investigated the early-age performance of cement combination concretes containing fly ash, silica fume, and metakaolin by considering their heat of hydration and compressive strength with a view to ascertaining their suitability for concrete works at early ages.

\section{Materials and Experimental Methods}

The cementitious materials consisted of ordinary Portland cement (PC, 42.5-type) conforming to BS EN 197-1 [27], siliceous or class F fly ash (FA) conforming to BS EN 450-1 [28], silica fume (SF, 
slurry- 50:50 solid/water ratio by mass) conforming to BS EN 13263 [29], and metakaolin (MK, Meta Star 403) treated as calcined pozzolana conforming to BS EN 197-1 [27]. The physical and chemical properties of the cementitious materials are presented in Table 1 . The aggregates were consisted of $0 / 4 \mathrm{~mm}$ fine aggregates and $4 / 10 \mathrm{~mm}$ and $10 / 20 \mathrm{~mm}$ coarse aggregates conforming to BS EN 12620 [30] and mixed in a ratio of 1:2 in line with the BRE Design Guide [31]. The coarse aggregates were uncrushed and in various shapes. The $4 / 10 \mathrm{~mm}$ aggregates have rough texture while the $10 / 20 \mathrm{~mm}$ aggregates were smooth. The physical properties of the aggregates are presented in Table 2. Potable water, conforming to BS EN 1008 [32], was used for mixing and curing the concrete specimens. For good cohesion within a consistence level of S2, defined by a nominal slump of 50-90 mm in BS EN 206-1 [33], a polycarboxylate ether superplasticiser conforming to BS EN 934-2 [34] was applied during concrete mixing. The mix proportions for the test mixes (Tables 3-5) were obtained using the BRE Design Guide [31], considering a normal density concrete $\left(2400 \mathrm{~kg} / \mathrm{m}^{3}\right)$, and a free water content of $165 \mathrm{~kg} / \mathrm{m}^{3}$ to ensure good concrete finish.

Concrete was prepared in accordance with BS EN 12390-2 [35] and the specimens were cast, cured under a layer of damp hessian and covered with polythene for about 24 hours, demoulded, and cured in water at $20^{\circ} \mathrm{C}$ until the test dates. Compressive strengths were obtained in accordance with BS EN 12390-3 [36] using $100 \mathrm{~mm}$ cubes and compared at the curing ages of $1,2,3,5$, and 7 days and a water/cement ratio of 0.50 . Since Portland cement (42.5 type) is expected to achieve a minimum strength of $10.0 \mathrm{~N} / \mathrm{mm}^{2}$ at 2 days to be classified as having ordinary early-age strength and a minimum strength of $20.0 \mathrm{~N} / \mathrm{mm}^{2}$ at 2 days to be classified as having high early-age strength [27], the compressive strength of concrete were also examined to ascertain their suitability for concrete works requiring ordinary and high early-age strength development.

Heat of hydration was obtained with JAF Isothermal Conduction Calorimeter [37]. The heat of hydration generated by each of the paste samples, in a calorimeter maintained under isothermal conditions, was sent as electric signal (proportional to the heat produced by a sensitive thermopile) to the computer for recording and calibration. This involved mixing about $30 \mathrm{~g}$ of the cement(s) with about $15 \mathrm{~g}$ (or slightly higher for mixtures containing silica fume or metakaolin) of distilled water in a plastic bag for about 1 minute by hand. The bag containing the mixed paste was then sealed and placed in a sample container containing $10 \mathrm{ml}$ of heat conducting oil. The bag was wrapped around the heater disk of the sample container to ensure that contact with the heater disk was maintained. The sample container connected to the computer was placed in the calorimeter and insulating foam was used to prevent heat loss through the Perspex surface. The calorimeter was sealed water-tight and placed in a water bath maintained at a constant temperature of about $20^{\circ} \mathrm{C}$. The heat of hydration generated over 72 hours from the start of the test was progressively recorded and calibrated with the aid of the JAF software on the computer connected to the test set-up.

\section{Analysis and Discussion of Results}

\section{Heat of Hydration of Cement}

The total heat of hydration generated by Portland cement and binary and ternary cement combinations at 24, 48, and 72 hours are presented in Table 3. Table 3 also presents the heat factors (i.e., heat ratios with respect to Portland cement) of the cement combinations at the test ages. The Table shows that the total heat generated increased with increasing test age. At the test ages, in line with Thomas et al. [5] and Paine et al. [7], the heat of hydration of fly ash binary cements were lower than that of ordinary Portland cement and they were reduced with increasing content of fly ash. This is probably due to the dilution effect as a result of reduction in the Portland cement content and amount of $\mathrm{Ca}(\mathrm{OH})_{2}$ available for pozzolanic reaction. Comparatively, the heat of hydration of silica fume (SF) and metakaolin (MK) binary cements at 24 hours were higher than that of Portland cement at addition contents of not greater than $10 \%$ and they increased with increasing test age such that at 48 hours onwards all the binary cements (including the mix with $15 \%$ MK content with heat of hydration lower than that of Portland cement at 24 hours), had higher heat of hydration than Portland cement. The heat of hydration increased with increasing content of silica fume and metakaolin, despite the dilution effect. This is probably due to their fineness and higher specific surface area available for pozzolanic reaction $[11,12]$. Compared with the respective fly ash binary cement combinations, the addition of silica fume and metakaolin as ternary cement components resulted in ternary cements with higher heat of hydration. It increased with increasing contents of the ternary cement components. Hence, while fly ash would slower pozzolanic reaction, its lower heat value would make it good for mass concrete or concrete work in hot weather. Silica fume and metakaolin, on the other, would accelerate pozzolanic reaction and support concrete work in cold weather. Also, compared with metakaolin, the fineness of silica fume must have resulted in the higher heat values obtained for the silica fume binary and ternary mixes at equal replacement levels. 
Table 1. Physical and Chemical Properties of Cements

\begin{tabular}{|c|c|c|c|c|}
\hline \multirow{2}{*}{ Property } & \multicolumn{4}{|c|}{ Cements } \\
\hline & CEM I & FA & MK & $\mathrm{SF}$ \\
\hline Blaine fineness, $\mathrm{m}^{2} / \mathrm{kg}$ & 395 & 388 & 2588 & $*$ \\
\hline Loss on ignition, \% a) & 1.9 & $6.1^{b)}$ & 0.9 & 2.7 \\
\hline Particle density, $\mathrm{g} / \mathrm{cm}^{3}$ & 3.17 & 2.26 & 2.51 & 2.17 \\
\hline$\%$ retained by $45 \mu \mathrm{m}$ sieve $\left.{ }^{b}\right)$ & - & 11.0 & - & - \\
\hline \multicolumn{5}{|c|}{ Particle size distribution, cumulative $\%$ passing by mass $\left.{ }^{c}\right)$} \\
\hline $125 \mu \mathrm{m}$ & 100 & 100 & 100 & 100 \\
\hline $100 \mu \mathrm{m}$ & 98.2 & 99.2 & 100 & 100 \\
\hline $75 \mu \mathrm{m}$ & 93.2 & 96.5 & 99.8 & 100 \\
\hline $45 \mu \mathrm{m}$ & 81.8 & 87.0 & 99.4 & 100 \\
\hline $25 \mu \mathrm{m}$ & 57.1 & 66.2 & 96.0 & 98.8 \\
\hline $10 \mu \mathrm{m}$ & 30.1 & 40.6 & 76.2 & 93.8 \\
\hline $5 \mu \mathrm{m}$ & 13.5 & 24.1 & 50.7 & 87.5 \\
\hline $2 \mu \mathrm{m}$ & 5.6 & 10.9 & 18.2 & 85.5 \\
\hline $1 \mu \mathrm{m}$ & 2.9 & 4.8 & 4.7 & 78.7 \\
\hline $0.7 \mu \mathrm{m}$ & 1.3 & 1.9 & 1.4 & 50.7 \\
\hline $0.5 \mu \mathrm{m}$ & 0.2 & 0.3 & 0.1 & 10.5 \\
\hline \multicolumn{5}{|l|}{ Bulk oxide composition, \% d) } \\
\hline $\mathrm{CaO}$ & 64.5 & 3.2 & 0.0 & 0.4 \\
\hline $\mathrm{SiO}_{2}$ & 20.0 & 52.0 & 57.6 & 96.6 \\
\hline $\mathrm{Al}_{2} \mathrm{O}_{3}$ & 4.6 & 26.0 & 38.9 & 0.7 \\
\hline $\mathrm{Fe}_{2} \mathrm{O}_{3}$ & 3.7 & 10.1 & 0.6 & 0.2 \\
\hline $\mathrm{MgO}$ & 2.5 & 1.5 & 0.3 & 0.6 \\
\hline $\mathrm{MnO}$ & 0.1 & 0.1 & 0.0 & 0.0 \\
\hline $\mathrm{TiO}_{2}$ & 0.3 & 1.5 & 0.0 & 0.0 \\
\hline $\mathrm{K}_{2} \mathrm{O}$ & 0.7 & 2.8 & 2.4 & 0.8 \\
\hline $\mathrm{Na}_{2} \mathrm{O}$ & 0.3 & 1.2 & 0.1 & 0.3 \\
\hline $\mathrm{P}_{2} \mathrm{O}_{5}$ & 0.1 & 0.5 & 0.1 & 0.1 \\
\hline $\mathrm{Cl}$ & 0.1 & 0.0 & 0.0 & 0.1 \\
\hline $\mathrm{SO}_{3}$ & 3.1 & 1.1 & 0.0 & 0.2 \\
\hline
\end{tabular}

* Fineness for $\mathrm{SF}=15,000-30,000 \mathrm{~m}^{2} / \mathrm{kg}[21]$

a) In accordance with BS EN 196-2 [38]

b) In accordance with BS EN 450-1 [28]

c) Obtained with the Laser Particle Sizer

d) Obtained by x-ray fluorescence (XRF)

Table 2. Physical Properties of Fine and Coarse Laboratory-Dry Aggregates

\begin{tabular}{lccc}
\hline \multicolumn{1}{c}{ Property } & Fine Aggregates & \multicolumn{2}{c}{ Coarse Aggregates } \\
\cline { 3 - 4 } & $0 / 4 \mathrm{~mm}$ & $4 / 10 \mathrm{~mm}$ & $10 / 20 \mathrm{~mm}$ \\
\hline Shape, visual & - & Varied & Varied \\
Surface texture, visual & - & Rough & 2.6 \\
Particle density a) & 2.6 & 2.6 & 1.2 \\
Water absorption, \% a) & 1.0 & 1.7 & - \\
\% passing 600 $\mu \mathrm{m}$ sieve & 55.0 & - &
\end{tabular}

\section{Early-age Compressive Strength of Concrete}

The cube compressive strength of Portland cement and binary and ternary cement concretes at the ages of $1,2,3,5$, and 7 days are presented in Table 4. Cube compressive strength, as expected, increased with increasing curing age. The cube compressive strengths of fly ash binary cement concretes are lower than that of ordinary Portland cement concrete $[9,10]$ and they reduced with increasing content of fly ash at all the curing ages. This is probably due to the slow pozzolanic reaction of fly ash [8] as a result of the heat of hydration reducing with in- creasing content of fly ash. However, while the fly ash binary cement concretes have lower strength at equal ages than ordinary Portland cement concrete, their strength factors (i.e. strength ratios with respect to ordinary Portland cement concrete) increased with increasing age from $79 \%, 50 \%$, and $33 \%$ at 24 hours to $82 \%, 58 \%$, and $36 \%$ at 7 days at $20 \%$, $35 \%$, and $55 \%$ fly ash content, respectively (Table 5). The reduction in the disparity between the compressive strength of Portland cement concrete and the fly ash binary cement concrete must be due to the increasing heat of hydration and improved pozzolanic reaction of fly ash with increasing age. 
Table 3. Total Heat of Hydration and Heat Factors of Cements

\begin{tabular}{lrrrrrr}
\hline \multicolumn{1}{c}{ Mix Combination } & \multicolumn{3}{c}{ Heat of Hydration, kJ/kg } & \multicolumn{3}{c}{ Heat Factors, \% a) } \\
\cline { 2 - 6 } & 24 hours & 48 hours & 72 hours & 24 hours & 72 hours & 72 hours \\
\hline $100 \% \mathrm{PC}$ & 178.0 & 226.5 & 226.5 & 100 & 100 & 100 \\
$80 \% \mathrm{PC}+20 \% \mathrm{FA}$ & 152.0 & 195.0 & 222.2 & 85.4 & 86.1 & 86.9 \\
$80 \% \mathrm{PC}+15 \% \mathrm{FA}+5 \% \mathrm{MK}$ & 166.1 & 211.6 & 239.2 & 93.3 & 93.4 & 93.5 \\
$80 \% \mathrm{PC}+15 \% \mathrm{FA}+5 \% \mathrm{SF}$ & 167.0 & 213.5 & 242.8 & 93.8 & 94.3 & 94.9 \\
$65 \% \mathrm{PC}+35 \% \mathrm{FA}$ & 129.9 & 166.3 & 188.4 & 73.0 & 73.4 & 73.7 \\
$65 \% \mathrm{PC}+30 \% \mathrm{FA}+5 \% \mathrm{MK}$ & 131.9 & 169.0 & 191.4 & 74.1 & 74.6 & 74.8 \\
$65 \% \mathrm{PC}+25 \% \mathrm{FA}+10 \% \mathrm{MK}$ & 139.9 & 187.3 & 213.3 & 78.6 & 82.7 & 83.5 \\
$65 \% \mathrm{PC}+30 \% \mathrm{FA}+5 \% \mathrm{SF}$ & 144.7 & 186.6 & 212.3 & 81.3 & 82.4 & 83.0 \\
$65 \% \mathrm{PC}+25 \% \mathrm{FA}+10 \% \mathrm{SF}$ & 148.0 & 189.1 & 215.0 & 83.1 & 83.5 & 84.1 \\
$45 \% \mathrm{PC}+55 \% \mathrm{FA}$ & 96.0 & 126.0 & 146.9 & 53.9 & 55.6 & 57.4 \\
$45 \% \mathrm{PC}+45 \% \mathrm{FA}+10 \% \mathrm{MK}$ & 100.7 & 137.4 & 156.3 & 56.6 & 60.7 & 61.1 \\
$45 \% \mathrm{PC}+40 \% \mathrm{FA}+15 \% \mathrm{MK}$ & 96.5 & 133.6 & 153.1 & 54.2 & 59.0 & 59.9 \\
$45 \% \mathrm{PC}+45 \% \mathrm{FA}+10 \% \mathrm{SF}$ & 111.2 & 143.4 & 163.2 & 62.5 & 63.3 & 63.8 \\
$95 \% \mathrm{PC}+5 \% \mathrm{MK}$ & 191.2 & 244.2 & 276.3 & 107.4 & 107.8 & 108.0 \\
$90 \% \mathrm{PC}+10 \% \mathrm{MK}$ & 193.3 & 247.5 & 280.4 & 108.6 & 109.3 & 109.6 \\
$85 \% \mathrm{PC}+15 \% \mathrm{MK}$ & 176.6 & 232.7 & 265.2 & 99.2 & 102.7 & 103.7 \\
$95 \% \mathrm{PC}+5 \% \mathrm{SF}$ & 195.3 & 249.4 & 285.5 & 109.7 & 110.1 & 111.6 \\
$90 \% \mathrm{PC}+10 \% \mathrm{SF}$ & 196.2 & 250.7 & 286.5 & 110.2 & 110.7 & 112.0 \\
\hline
\end{tabular}

a) Heat ratios determined with respect to $\mathrm{PC}$ values

Table 4. Cube Compressive Strengths of Concretes

\begin{tabular}{|c|c|c|c|c|c|}
\hline \multirow{2}{*}{ Mix Combination } & \multicolumn{5}{|c|}{ Cube Compressive Strength, $\mathrm{N} / \mathrm{mm}^{2}$} \\
\hline & $1 \mathrm{~d}$ & $2 \mathrm{~d}$ & $3 d$ & $5 \mathrm{~d}$ & $7 \mathrm{~d}$ \\
\hline $100 \% \mathrm{PC}$ & 12.0 & 24.0 & 32.0 & 39.5 & 43.5 \\
\hline $80 \% \mathrm{PC}+20 \% \mathrm{FA}^{\mathrm{o}, \mathrm{h}}$ & 9.5 & 19.0 & 25.5 & 32.0 & 36.0 \\
\hline $80 \% \mathrm{PC}+15 \% \mathrm{FA}+5 \% \mathrm{MK}^{\mathrm{o}, \mathrm{h}}$ & 10.0 & 20.0 & 27.0 & 34.0 & 39.0 \\
\hline $80 \% \mathrm{PC}+15 \% \mathrm{FA}+5 \% \mathrm{SF}^{\mathrm{o}, \mathrm{h}}$ & 10.0 & 20.5 & 27.5 & 35.0 & 40.5 \\
\hline $65 \% \mathrm{PC}+35 \% \mathrm{FA}^{\circ}$ & 6.0 & 12.0 & 16.5 & 21.5 & 25.0 \\
\hline $65 \% \mathrm{PC}+30 \% \mathrm{FA}+5 \% \mathrm{MK}^{\circ}$ & 6.5 & 13.5 & 18.5 & 24.0 & 28.0 \\
\hline $65 \% \mathrm{PC}+25 \% \mathrm{FA}+10 \% \mathrm{MK}^{\circ}$ & 7.5 & 15.0 & 20.5 & 26.5 & 31.0 \\
\hline $65 \% \mathrm{PC}+30 \% \mathrm{FA}+5 \% \mathrm{SF}^{\circ}$ & 7.0 & 14.0 & 19.5 & 25.0 & 29.5 \\
\hline $65 \% \mathrm{PC}+25 \% \mathrm{FA}+10 \% \mathrm{SF}^{\circ}$ & 7.5 & 15.5 & 21.0 & 27.5 & 33.0 \\
\hline $45 \% \mathrm{PC}+55 \% \mathrm{FA}$ & 4.0 & 8.0 & 11.0 & 14.0 & 15.5 \\
\hline $45 \% \mathrm{PC}+45 \% \mathrm{FA}+10 \% \mathrm{MK}^{\circ}$ & 4.5 & 9.5 & 13.0 & 17.5 & 20.5 \\
\hline $45 \% \mathrm{PC}+40 \% \mathrm{FA}+15 \% \mathrm{MK}$ & 4.5 & 9.0 & 12.5 & 16.5 & 19.5 \\
\hline $45 \% \mathrm{PC}+45 \% \mathrm{FA}+10 \% \mathrm{SF}^{\circ}$ & 5.0 & 10.5 & 14.0 & 19.0 & 22.0 \\
\hline $95 \% \mathrm{PC}+5 \% \mathrm{MK}^{\mathrm{o}, \mathrm{h}}$ & 10.5 & 21.5 & 30.0 & 38.5 & 43.5 \\
\hline $90 \% \mathrm{PC}+10 \% \mathrm{MK}^{\mathrm{o}, \mathrm{h}}$ & 10.5 & 22.0 & 30.5 & 39.0 & 44.0 \\
\hline $85 \% \mathrm{PC}+15 \% \mathrm{MK}^{\mathrm{o}, \mathrm{h}}$ & 10.0 & 20.0 & 28.5 & 37.0 & 42.0 \\
\hline $95 \% \mathrm{PC}+5 \% \mathrm{SF}^{\circ, \mathrm{h}}$ & 11.0 & 22.5 & 31.0 & 39.5 & 44.5 \\
\hline $90 \% \mathrm{PC}+10 \% \mathrm{SF}^{\circ, \mathrm{h}}$ & 11.0 & 23.0 & 31.5 & 40.5 & 45.0 \\
\hline
\end{tabular}

${ }^{\circ}$ Cement combinations that meet the strength requirement of ordinary early-age performance

${ }^{\mathrm{h}}$ Cement combinations that meet the strength requirement of high early-age performance

Compared with Portland cement, silica fume and metakaolin as binary cement components also reduced the compressive strength of concrete (Table 4). However, based on their comparatively higher strength factors which increased with increasing age from $83-92 \%$ at 24 hours to $97-104 \%$ at 7 days (Table 5), they resulted in better strength development than fly ash. Hence, they have comparable or higher compressive strength than Portland cement concrete at 7 days (Table 4). This is probably due to their higher heat of hydration (Table 3) and higher silica content and fineness (Table 1), resulting in more nucleation sites to improve their pozzolanic reactivity. Hence, the addition of silica fume and metakaolin as ternary cement components to Portland cement and fly ash resulted in ternary cement concrete with higher strength than the respective fly ash binary cement concrete at equal ages (Table 4). Also, the increasing compressive strength and strength factors of the binary and ternary cement concrete with increasing curing age (Tables 4 and 5) must be due to improved pozzolanic reactions of the supplementary cements: 
Table 5. Strength Factors of Concrete

\begin{tabular}{|c|c|c|c|c|c|}
\hline \multirow{2}{*}{ Mix Combination } & \multicolumn{5}{|c|}{ Strength Factors, \% a) } \\
\hline & $1 d$ & $2 \mathrm{~d}$ & $3 \mathrm{~d}$ & $5 \mathrm{~d}$ & $7 d$ \\
\hline $100 \% \mathrm{PC}$ & 100 & 100 & 100 & 100 & 100 \\
\hline $80 \% \mathrm{PC}+20 \% \mathrm{FA}$ & 79 & 79.5 & 80 & 81 & 82 \\
\hline $80 \% \mathrm{PC}+15 \% \mathrm{FA}+5 \% \mathrm{MK}$ & 83 & 83.5 & 84 & 86 & 90 \\
\hline $80 \% \mathrm{PC}+15 \% \mathrm{FA}+5 \% \mathrm{SF}$ & 83 & 85 & 86 & 89 & 93 \\
\hline $65 \% \mathrm{PC}+35 \% \mathrm{FA}$ & 50 & 50 & 52 & 54 & 58 \\
\hline $65 \% \mathrm{PC}+30 \% \mathrm{FA}+5 \% \mathrm{MK}$ & 54 & 56 & 58 & 61 & 64 \\
\hline $65 \% \mathrm{PC}+25 \% \mathrm{FA}+10 \% \mathrm{MK}$ & 63 & 63 & 64 & 67 & 71 \\
\hline $65 \% \mathrm{PC}+30 \% \mathrm{FA}+5 \% \mathrm{SF}$ & 58 & 58.5 & 61 & 63 & 68 \\
\hline $65 \% \mathrm{PC}+25 \% \mathrm{FA}+10 \% \mathrm{SF}$ & 63 & 64.5 & 66 & 70 & 76 \\
\hline $45 \% \mathrm{PC}+55 \% \mathrm{FA}$ & 33 & 33.5 & 34 & 35 & 36 \\
\hline $45 \% \mathrm{PC}+45 \% \mathrm{FA}+10 \% \mathrm{MK}$ & 38 & 39.5 & 41 & 44 & 47 \\
\hline $45 \% \mathrm{PC}+40 \% \mathrm{FA}+15 \% \mathrm{MK}$ & 38 & 38 & 39 & 42 & 45 \\
\hline $45 \% \mathrm{PC}+45 \% \mathrm{FA}+10 \% \mathrm{SF}$ & 41.5 & 41.5 & 44 & 48 & 51 \\
\hline $95 \% \mathrm{PC}+5 \% \mathrm{MK}$ & 88 & 89.5 & 94 & 98 & 100 \\
\hline $90 \% \mathrm{PC}+10 \% \mathrm{MK}$ & 88 & 91.5 & 95 & 99 & 101 \\
\hline $85 \% \mathrm{PC}+15 \% \mathrm{MK}$ & 83 & 83.5 & 89 & 94 & 97 \\
\hline $95 \% \mathrm{PC}+5 \% \mathrm{SF}$ & 91.5 & 94 & 97 & 100 & 102 \\
\hline $90 \% \mathrm{PC}+10 \% \mathrm{SF}$ & 92 & 96 & 98 & 102 & 104 \\
\hline
\end{tabular}

a) Strength ratios determined with respect to $\mathrm{PC}$ values

Hence, silica fume and metakaolin would improve early-age performance of concrete. Tables 4 and 5 show that while the compressive strength of metakaolin binary and ternary cement concrete increased up to $10 \% \mathrm{MK}$ content, the compressive strength at $15 \% \mathrm{MK}$ content were lower than that of mixes with $10 \%$ MK content. Since there is no beneficial effect of using $15 \%$ MK over $10 \%$ MK on strength development, metakaolin content should be limited to $10 \%$ content where compressive strength is the deciding performance criterion.

At 2 days, BS EN 197- 1 [27] requires a 42.5 type Portland cement (used in this research) to achieve a minimum compressive strength of $10.0 \mathrm{~N} / \mathrm{mm}^{2}$ to meet the strength requirement for ordinary earlyage performance and a minimum compressive strength of $20.0 \mathrm{~N} / \mathrm{mm}^{2}$ to meet the strength requirement for high early-age performance. Hence, the probability of acceptance of $5 \%$ allowed by BS EN 197-1 [27], would result in a minimum strength range of $9.5-10.0 \mathrm{~N} / \mathrm{mm}^{2}$ for ordinary early-age performance and 19.0-20.0 N/mm² for high early-age performance. Based on the foregoing, 15 out of the 17 cement combinations investigated met the strength requirement of ordinary early-age performance and eight of the cement combinations met the strength requirement of high early-age performance (Table 4). Hence, cement combinations, if appropriately proportioned, would produce concrete with good early-age performance.

\section{Relationship between the Heat of Hydration of Cement and Compressive Strength of Concrete}

Figure 1 illustrates the relationship between the heat of hydration of cement at 24 and 72 hours and compressive strength of concrete at 1 and 3 days, respectively. The high correlation obtained between the compressive strength and total heat of hydration shows that the heat of hydration would influence early-age strength development. However, the comparison of the heat factors (Table 3) with the strength factors (Table 5) shows that the heat factors were higher than the strength factors for all mixes. For example, silica fume and metakaolin which have higher heat factors than Portland cement have lower strength factors than Portland cement. This disparity must be due to the fact that while heat of hydration was carried out on paste samples, compressive strength was carried out on concrete specimens. It therefore follows that part of the heat of hydration generated by the cements must have been lost to the aggregates in concrete. Also, due to its fineness and higher heat and strength values or factors (Tables 3-5), silica fume performed better than metakaolin at equal replacement levels.
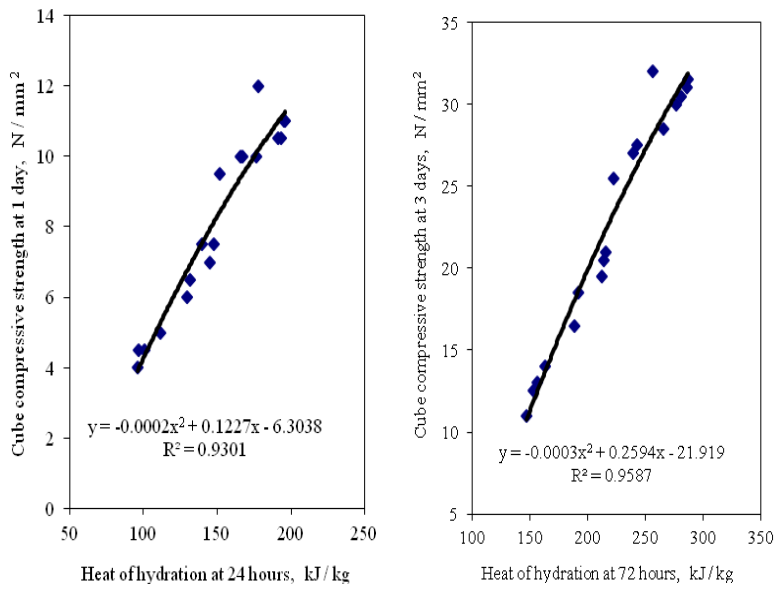

Figure 1. Correlation between Concrete Strengths and Heats of Hydration of Cements 


\section{Conclusion}

This study has investigated the effect of 17 binary and ternary cement combinations containing fly ash, silica fume, and metakaolin on the heat of hydration and early-age strength development of cement combination concrete. The following conclusions have been drawn from the study.

1. Early-age strength development in cement combination concrete is influenced by heat of hydration.

2. Fly ash reduces early-age strength, due to dilution effect, low heat of hydration, and low pozzolanic reactivity. Hence, fly ash concrete or high volume fly ash concrete will produce low heat cement suitable for mass concrete work or concrete work in hot weather.

3. Using Silica fume and metakaolin as binary cement components produces concrete with earlyage strength comparable or higher than that of Portland cement concrete. This is due to their fineness, higher heat of hydration and higher pozzolanic reactivity. As ternary cement components, silica fume and metakaolin complement fly ash in ternary mixes. For optimum result, their content should be limited to $10 \%$. Also, silica fume, due to its fineness, performs better than metakaolin at equal replacement levels.

4. Most of the binary and ternary cements investigated $(88 \%)$ met the strength requirement for ordinary early-age performance, while only half of them of them (47\%) met the strength requirement for high early-age performance of concrete. Hence, if appropriately proportioned, cement combination could be used to produce concrete with good early-age performance.

\section{References}

1. Parrott, L.J., Cement, Concrete, and Sustainability, A Report on the Progress of the UK Cement and Concrete Industry Towards Sustainability, British Cement Association, UK, 2002.

2. The Construction Industry Sustainable Concrete Forum, 2009. Available at: http://www.sustainableconcrete.org.uk. Accessed on November 9, 2016.

3. Jones, M.R., Sear, L.K.A., McCarthy, M.J. and Dhir, R.K., Changes in Coal Fired Power Station Fly Ash: Recent Experiences and Use in Concrete, Proceding of the Ash Technology Conference, UK Quality Ash Association, Birmingham, 2006, Available at: www.ukqaa.org.uk/ index_htm_files/AshTechA01ChangesInCoalFired PowerStationJonesEtAl.pdf, Accessed July 18, 2015.

4. Antiohos, S.K., Papadakis, V.G., Chaniotakis, E., and Tsimas, S., Improving the Performance of
Ternary Blended Cements by Mixing Different Types of Fly Ashes, Cement and Concrete Research, 37(6), 2007, pp. 877-885.

5. Thomas, M.D.A., Shehata, M.H., Shashiprakash, S.G., Hopkins, D.S., and Cail, K., Use of Ternary Cementitious Systems Containing Silica Fume and Fly Ash in Concrete, Cement and Concrete Research, 29(8), 1999, pp. 1207-1214.

6. Dhir, R.K., McCarthy, M.J., and Paine, K.A., Use of Fly Ash to BS EN 450 in Structural Concrete, Thomas Telford, 2002.

7. Paine, K.A., Zheng, L., and Dhir, R.K., Experimental Study and Modeling of Heat Evolution of Blended Cements, Advances in Cement Research, 17, 2005, pp. 121-132.

8. Bilodeau, A. and Malhotra, V.M., High Volume Fly Ash System, Concrete Solution for Sustainable Development, 97(1), 2000, pp. 41-48.

9. Hassan, K.E., Cabrera, J.G., and Maliehe, R.S., The Effect of Mineral Admixtures on the Properties of High-Performance Concrete, Cement and Concrete Composites, 22(4), 2000, pp. 267-271.

10. McCarthy, M.J. and Dhir, R.K., Development of High Volume Fly Ash Cements for Use in Concrete Construction, Fuel, 84, 2005, pp. 14231432.

11. Sanchez de Rojas, M.I. and Frias, M., The Pozzolanic Activity of Different Materials, Its Influence on the Hydration Heat in Mortars, Cement and Concrete Research, 26(2), 1996, pp. 203-213.

12. Frias, M., Sanchez de Rojas, M.I., and Cabrera, G. J., The Effect that the Pozzolanic Reaction of Metakaolin has on the Heat Evolution in Metakaolin-Cement Mortars, Cement and Concrete Research, 30(2), 2000, pp. 209-216.

13. Wild, S., Sabir, B.B. and Khatib, J.M., Factors Influencing Strength Development of Concrete Containing Silica Fume, Cement and Concrete Research, 25(7), 1995, pp. 1567-1580.

14. Mehta, P.K. and Aitcin, P.C., Principles Underlying Production of High-Performance Concrete, Cement, Concrete and Aggregates, 12(2), 1990, pp. 70-78.

15. Wild, S., Khatib, J.M., and Jones, A., Relative Strength, Pozzolanic Activity and Cement Hydration in Superplasticised Metakaolin Concrete, Cement and Concrete Research, 26(10), 1996, pp. 1537- 1544.

16. Bai, J., Sabir, B.B., Wild, S., and Kinuthia, J.M., Strength Development in Concrete Incorporating PFA and Metakaolin, Magazine of Concrete Research, 52(3), 2000, pp. 153-162.

17. Langan, B.W., Weng, K., and Ward, M.A., 2002, Effect of Silica Fume and Fly Ash on Heat of Hydration of Portland Cement, Cement and Concrete Research, 32(7), 2002, pp. 1045-1051. 
18. Poon, C.S., Kou, S.C., and Lam, L., Compressive Strength, Chloride Diffusivity and Pore Structure of High Performance Metakaolin and Silica Fume Concrete, Construction and Building Materials, 20, 2006, pp. 858-865.

19. Holland, T.C., Silica Fume User's Manual, Technical Report, Silica Fume Association, Lovettsville, VA 22180, USA, 2005.

20. Dunster, A., Silica Fume in Concrete, Technical Information Paper (IP 5/09), Building Research Establishment, 2009.

21. Advanced Cement Technologies available at http://www.advancedcementtechnologies.com. Accessed July 18, 2015.

22. Shehata, M.H. and Thomas, M.D.A., Use of Ternary Blends Containing Silica Fume and Fly Ash to Suppress Expansion due to AlkaliSilica Reaction in Concrete, Cement and Concrete Research, 32(3), 2002, pp. 341-349.

23. Folagbade, S.O. and Newlands, M.D., Suitability of Cement Combinations for Carbonation Resistance of Structural Concrete, Journal of Engineering, Design and Technology, Emerald Publications, UK, 12(4), 2014, pp. 423-439.

24. Folagbade, S.O., Absorption Characteristics of Cement Combination Concrete Containing Portland Cement, Fly Ash, and Metakaolin, Civil Engineering Dimension, 18(1), 2016, pp. 5764.

25. Bai, J. and Wild, S., Investigation of the Temperature Change and Heat Evolution of Mortar Incorporating PFA and Metakaolin, Cement and Concrete Composite, 24(2), 2002, pp. 201-209.

26. Snelson, D.G., Wild, S. and O'Farrell, M., Heat of Hydration of Portland Cement-Metakaolin-Fly Ash (PC-MK-PFA) Blends, Cement and Concrete Research, 38(6), 2008, pp. 832-840.

27. BS EN 197-1, Cement- Part 1: Composition, Specifications and Conformity Criteria for Common Cements, British Standards Institution, 2000.
28. BS EN 450-1, Fly Ash for Concrete- Part 1: Definitions, Specifications and Conformity Criteria, British Standards Institution, 2002.

29. BS EN 13263, Silica Fume for Concrete, British Standards Institution, 2005.

30. BS EN 12620, Aggregates for Concrete, British Standards Institution, 2002.

31. Teychenne, D.C., Franklin, R.E., and Erntroy, H.C., Design of Normal Concrete Mixes, $2^{\text {nd }}$ Ed., Amended by B.K. Marsh, Building Research Establishment, 1997.

32. BS EN 1008, Mixing Water for Concrete- Specification for Sampling, Testing and Assessing the Suitability of Water, Including Water Recovered from Processes in the Concrete Industry, as Mixing Water for Concrete, British Standards Institution, 2002.

33. BS EN 206-1, Concrete- Part 1: Specification, Performance, Production, and Conformity, British Standards Institution, 2000.

34. BS EN 934-2, Admixtures for Concrete, Mortar and Grout- Part 2: Concrete Admixtures-Definitions, Requirements, Conformity, Marking, and Labelling, British Standards Institution, 2009.

35. BS EN 12390-2, Testing Hardened Concrete Part 2: Making and Curing Specimens for Strength Tests, British Standards Institution, 2000.

36. BS EN 12390-3, Testing Hardened Concrete Part 3: Compressive Strength of Test Specimens, British Standards Institution, 2002.

37. JAF Isothermal Conduction Calorimeter, available at http://www.mastrad.com. Accessed November 10, 2016.

38. BS EN 196-2, Methods for Testing Cement- Part 2: Chemical Analysis of Cement, British Standards Institution, 2005.

39. BS EN 1097-6, Tests for Mechanical and Physical Properties of Aggregates Part 6: Determination of Particle Density and Water Absorption, British Standards Institution, 2000. 